\title{
From oxidation to Paf the Dog: mental images of student engineers in EFL vocabulary association and retention
}

\section{Alex Boulton}

\section{OpenEdition \\ Journals}

\section{Electronic version}

URL: http://journals.openedition.org/asp/2033

DOI: $10.4000 /$ asp. 2033

ISBN: 978-2-8218-0382-4

ISSN: 2108-6354

Publisher

Groupe d'étude et de recherche en anglais de spécialité

\section{Printed version}

Date of publication: 31 December 2000

Number of pages: $33-47$

ISSN: $1246-8185$

\section{Electronic reference}

Alex Boulton, « From oxidation to Paf the Dog: mental images of student engineers in EFL vocabulary association and retention », ASp [Online], 27-30 | 2000, Online since 27 December 2010, connection on 01 May 2019. URL : http://journals.openedition.org/asp/2033 ; DOI : 10.4000/asp.2033

This text was automatically generated on 1 May 2019.

Tous droits réservés 


\title{
From oxidation to Paf the Dog: mental images of student engineers in EFL vocabulary association and retention
}

\author{
Alex Boulton
}

1 Vocabulary has frequently been identified as one of the major problems in second language (L2) learning, especially by the learners themselves (Meara 1982). However, the response of many teachers seems to be: ignore it and it will go away. Target vocabulary is simply presented, often as items in context which the learner has to a) identify as being target items, and b) just learn. While it is axiomatic that the teacher cannot do the learning for the student, this seems to be an unfair abnegation of responsibility: we cannot learn grammar for our students either, yet we spend countless hours presenting grammar in such a way that the learning process is, hopefully, facilitated. Why does the same approach not apply to vocabulary?

2 Admittedly, this lack of interest in vocabulary starts further upstream: while significant research into vocabulary learning has been carried out in recent years, it has not yet filtered down to the materials available. This relative dearth of vocabulary teaching aids may indicate to many teachers that it is not their job to teach it - though if learners identify vocabulary as a problem area, then it is difficult to see how it can not be our concern. More worryingly, teachers may conclude that vocabulary is simply unteachable; this second point seems to be right at the crux of the matter. While grammar is seen as a finite set of generatively productive rules, vocabulary is largely seen as a potentially infinite and confused amalgam of disparate items, highly resistant to regularisation. But this is hardly fair either: the lexicon of a language is subject to sets of formal and semantic rules and tendencies, projecting heavily on to the syntax of the language lexical systematisation is possible. It might therefore be concluded that vocabulary can 
profitably be exploited, at least in consciousness-raising sessions in the language classroom.

This is the subject of this paper. We begin with an overview of some of the more wellknown phenomena of vocabulary retention, before homing in on one particular aspect: the use of mental images.

\section{There's no such thing as random learning}

4 We begin here by looking at the fruits of decades of psycholinguistic research with special application to vocabulary learning. The title of this section owes something to Fromkin's (1971) landmark paper, "The non-anomalous nature of anomalous utterances". Although, as the title suggests, she was concerned with apparently anomalous performance or perceived errors by native speakers, it has often been inferred that apparently inexplicable or random linguistic performance of all types is in fact the result of nonrandom factors. With regard to the L2 learner's mental lexicon, two factors are often highlighted: firstly, the importance of lexical associations and groupings; secondly, the importance of lexical salience or markedness.

An experiment was designed to test, or perhaps rather to demonstrate, these two factors. The population sample consisted of a group of 86 first-year student engineers at ESSTIN, an engineering college in the north-east of France. Their level of English was estimated as being intermediate or upper-intermediate according to the standard placement test. The procedure was explained before the experiment began: a transparency with 25 words was shown for 40 seconds (see table 1). At the end of that time, the subjects were asked simply to write down as many of the words as they could remember, in any order.

It bears repeating that this experiment aims merely to replicate well-established findings in an easily accessible manner. of course, this experiment is only concerned with the short-term memorisation of a list, and not with the long-term meaningful retention. Furthermore, it concentrates on visual input, which may be treated significantly differently from oral input in most current processing models. However, the experiment does serve as a means of providing a more concrete focus to what can at times be a rather abstract domain. To benefit fully from the discussion that follows, the reader may like to do the experiment herself first - a pen and a piece of paper are all that are needed.

Table 1. Random words

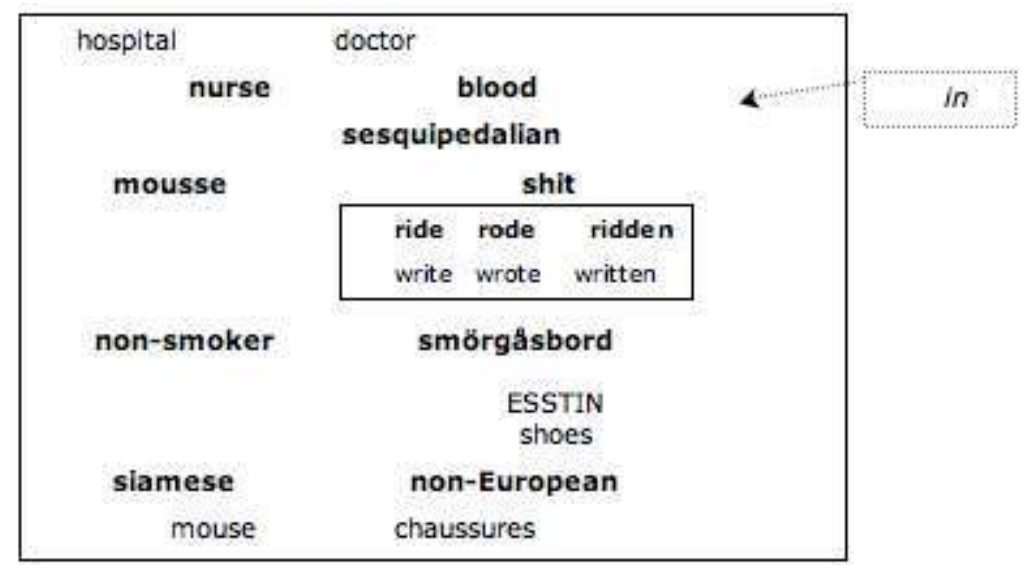


7 The students tested scored an average of 16.48 correct recalls; the highest score was 22 , the lowest $9 / 25$. The scores are presented below (table 2). These raw scores are in some ways an inflated and hence inaccurate reflection of purely random recall, due to the influence of groupings, as we shall see later. For example, most students remembered all of the group write/wrote/written and ride/rode/ridden; conversely, forgetting one meant forgetting all of them. We also allowed for minor spelling errors, but only insofar as the link was unambiguous: *sespiquedalian (for sesquipedalian) was accepted, while *bordsam (apparently for smörgåsbord) was not; shoe and shoes were both accepted as correct. For the 86 subjects in this experiment, not one added a single word not present on the initial stimulus list.

Table 2. Scores

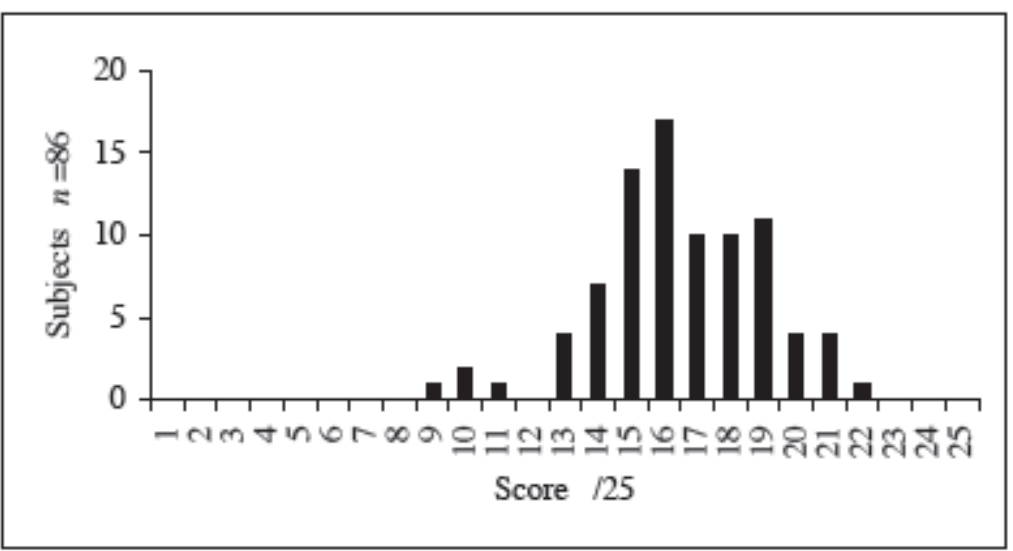

8 The focus of our attention however was on recall rates for particular items rather than on student scores. The percentage recall rates are detailed in table 3, and are the subject of the following discussion. It is possible to isolate the two main factors previously mentioned: the importance of grouping items together, and the importance of markedness.

Table 3. Recall rates

\begin{tabular}{|c|c|c|c|c|c|}
\hline hospital & \multirow{5}{*}{$84.88 \%$} & $\operatorname{sex}$ & $82.56 \%$ & shoes & \begin{tabular}{|l|}
54.65 \\
$\%$
\end{tabular} \\
\hline write & & nurse & $80.23 \%$ & non-smoker & $\begin{array}{l}47.67 \\
\%\end{array}$ \\
\hline wrote & & man & \multirow{2}{*}{$76.74 \%$} & shit & \multirow{2}{*}{$\begin{array}{l}46.51 \\
\%\end{array}$} \\
\hline written & & mouse & & cat & \\
\hline ride & & mousse & $73.26 \%$ & non-European & $\begin{array}{l}43.02 \\
\%\end{array}$ \\
\hline rode & \multirow{4}{*}{$83.72 \%$} & blood & $72.09 \%$ & Slamese & $\begin{array}{l}33.72 \\
\%\end{array}$ \\
\hline ridden & & doctor & $68.60 \%$ & sesquipedalian & $\begin{array}{l}17.44 \\
\%\end{array}$ \\
\hline ESSTIN & & chaussures & $62.79 \%$ & smorgăsbord & $5.81 \%$ \\
\hline woman & & & & & \\
\hline
\end{tabular}




\section{Lexical groupings}

9 Association is a functional characteristic of the human mind, and so the grouping of items to be retained is extremely important (Lindstromberg 1985). Access one item, and this creates a pathway to one or more others; the chances of recall are increased for the entire group, and the cognitive load is reduced. Research shows that virtually anything can be used to group words (Greene 1987: 19). McCarthy (1995) suggests giving any list of randomly chosen words to learners and asking them to group them: he claims that they will always find some connecting factor.

Some of the possible groupings are outlined below.

FORMAL: on the whole, formal associations may be less effective than semantic groups partly because they are generally not what the student is looking for (Champagnol 1974). However, recognition of such groups can often be prompted. For example, grammatical taxonomies can lead to the creation of groups, e.g. write/wrote/written and ride/rode/ridden , both scoring around $85 \%$. It is particularly noticeable that $81 \%$ of subjects recalled all 6 items, while $11 \%$ omitted them all. of the remainder, $5 \%$ recalled one group without the other, and only $3 \%$ recalled a partial group; this was invariably the infinitive, e.g. ride without rode or ridden. (Such results may in fact be less the result of imperfect recall than the result of time factors, incomplete understanding of the instructions, or even laziness.) These results are taken to indicate that irregular verb taxonomies have become so wellentrenched over the years through repeated teaching that they have come to be seen almost as a single item. There may also be additional associations between them, especially where formal similarities predominate, as is the case with write and ride. Spelling and pronunciation similarities can also link words, often reinforcing each other: for mouse and mousse, $65 \%$ of subjects recalled both items together, and $15 \%$ omitted both. In this case, we may also be dealing with a "double take": if students are unaware that mousse is an English word as well as a French word, they may check again to make sure they are dealing with two different items.

11 SEMANTIC: traditional semantic relationships most notably include synonymy. While no perfect synonyms exist from a linguist's point of view (either intralinguistically or interlinguistically), what counts is the learner's perception of synonymy. This may include translation equivalents: shoes and chaussures were correctly recalled as a pair by $49 \%$ of subjects, and omitted together by $31 \%$; only $20 \%$ recalled one item without the other. There are also various kinds of antonymy: woman and man were correctly recalled $72 \%$ of the time; only $16 \%$ did not pair the items. As an aside, woman (84\%) was slightly more frequently recalled than man (77\%), perhaps due to the preoccupations of 18-year-old male students in a predominantly male environment.

SCHEMATIC: this is perhaps the most obvious category, linking items which may co-occur in a typical situation. We are not far from schemata or script theory here: briefly, this is the idea that information (including vocabulary) is stored in mental networks according to its probable use in a given language community (Vigner 1989). For example, if you need to have your car repaired, the relevant script activates all the information you are likely to need for that situation, which provides a set of expectancies, thus reducing the cognitive load. One such field here includes the items doctor/nurse/hospital; $58 \%$ of subjects recalled all three items together. More interesting is the relative performance of the individual words in the group (for which we may include blood): where at least two 
items were recalled together, hospital was omitted less than $6 \%$ of the time and nurse only $10 \%$, while blood and doctor were forgotten each in about $21 \%$ of cases. The entire range of figures for this group is presented in table 4 .

Table 4: Groupings

\begin{tabular}{|c|c|c|c|c|c|}
\hline \multirow{2}{*}{$\begin{array}{c}\text { number } \\
\text { recalled }\end{array}$} & \multicolumn{4}{|c|}{ ITEMS RECALLED } & subjects \\
\cline { 2 - 6 } & hospital & nurse & doctor & blood & $(\%)$ \\
\hline 4 & $\mathrm{X}$ & $\mathrm{X}$ & $\mathrm{X}$ & $\mathrm{X}$ & $40.7 \%$ \\
\hline \multirow{4}{*}{3} & $\mathrm{X}$ & $\mathrm{X}$ & $\mathrm{X}$ & & $17.4 \%$ \\
\cline { 2 - 6 } & $\mathrm{X}$ & $\mathrm{X}$ & & $\mathrm{X}$ & $14.0 \%$ \\
\cline { 2 - 6 } & $\mathrm{X}$ & & $\mathrm{X}$ & $\mathrm{X}$ & $5.8 \%$ \\
\cline { 2 - 6 } & & $\mathrm{X}$ & $\mathrm{X}$ & $\mathrm{X}$ & $2.3 \%$ \\
\hline \multirow{4}{*}{2} & $\mathrm{X}$ & $\mathrm{X}$ & & & $3.5 \%$ \\
\cline { 2 - 6 } & $\mathrm{X}$ & & & $\mathrm{X}$ & $2.3 \%$ \\
\cline { 2 - 6 } & & & $\mathrm{X}$ & $\mathrm{X}$ & $2.3 \%$ \\
\cline { 2 - 6 } & $\mathrm{X}$ & & $\mathrm{X}$ & & $0.0 \%$ \\
\cline { 2 - 6 } & & $\mathrm{X}$ & $\mathrm{X}$ & & $0.0 \%$ \\
\hline \multirow{4}{*}{1} & & & & & $1.2 \%$ \\
\cline { 2 - 6 } & & & & $\mathrm{X}$ & $3.5 \%$ \\
\cline { 2 - 6 } & & & $\mathrm{X}$ & & $0.0 \%$ \\
\hline 0 & & & & & $4.7 \%$ \\
\hline
\end{tabular}

of course, such groupings are only useful once their existence is noticed: most of the groups above are quite obvious because the items are situated close together on the page, while others may go unnoticed as they are geographically isolated. One example is the morphologically-related pair non-European and non-smoker. The recall rate for this pair was only $22 \%$, while $47 \%$ of subjects recalled one item without the other. However, this can be partly accounted for by lower overall success rates $-43 \%$ and $48 \%$ respectively. What is important as far as teaching is concerned is to make sure that students perceive useful groups, and become accustomed to creating their own groups.

\section{Lexical markedness}

In general, any item which is considered to be "marked" is remarkable for that very reason, and hence more easily retained (Boulton 1999: 85-88). Some forms of markedness which are apparent from this experiment include the following:

VISUAL MARKEDNESS: we have already noted that the groups write/wrote/written and ride/ rode/ridden were the most successfully-recalled items, partly because they were boxed together in a visually remarkable way in the middle of the transparency. The first word on the page also tends to be positionally marked: $85 \%$ of students recalled hospital, but only $47 \%$ recalled the last item (cat), perhaps because it was somewhat obscure at the bottom of a rather long list. This is a variation on the "bathtub effect" (Aitchison 1994): in the bath, your head and (to a lesser extent) your feet stick out - they are the most salient points, and the easiest to remember. Aitchison is in fact talking about the beginning and ends of words, but the same reasoning applies to the beginnings and ends of lists: the words in the middle are the most difficult to remember. The conclusion is simple: it is easier to learn several short lists rather than one long list. Other types of formal markedness include the following (their relative importance may be deduced from the figures): the word in capitals (ESSTIN: 84\%); the word in red (blood: 72\%), reinforcing the 
meaning; the use of a different font (Siamese: 34\%); and the word with unusual symbols ( smörgåsbord: 5.8\%).

ACCESSIBILITY: more accessible items pose fewer cognitive problems, but may also be less marked. Word length may be important here: sex (83\%) had a higher recall rate than sesquipedalian (17\% if we allow for very approximate spelling) or smörgåsbord (6\%). But length is only one aspect; the higher recall rate for the longer sesquipedalian may be attributed partly to the fact that it "looks" relatively French, and is quite easily pronounceable according to standard French phonotactic rules; smörgåsbord, on the other hand, may be perceived as a virtually random (or certainly foreign) string of letters. However, etymologically French words are often longer than the less familiar AngloSaxon ones in English, which may alter the importance of the length factor for French learners. We are also dealing with familiarity here, which makes certain items (e.g. mouse: $87 \%$, which students typically learn very early in their language career) more accessible, as many pathways are already in place in the mental lexicon, while unfamiliar items have no such hooks (e.g. smörgåsbord). This point also concerns cognates (e.g. mousse 73\%), which are frequently better remembered than unrelated L2 items, as they already have a well-established place in the L1 lexicon. On the other hand, when unfamiliarity engenders markedness, it can lead to increased retention - it is perhaps surprising that sesquipedalian had as much as a $17 \%$ recall rate.

AFFECT: words which have personal or situational importance are more likely to be retained. It is scarcely surprising that ESSTIN elicited an $84 \%$ recall rate as it is the name of the students' college. Situation is important too: students may long remember the exact context where they first encountered a word. Items perceived as surprising in the context may also be well retained: sex achieved $83 \%$ recall, perhaps because the students are not traditionally used to talking about sex in the language classroom. Few data are perfect, though: it is perhaps surprising that shit only produced a $47 \%$ recall rate, especially as it has been borrowed into French as a common slang term for drugs. Interestingly, virtually any word can take on (or be made to take on) such affective dimensions. Quite idiosyncratically, students may like the sound of a word, or remember items such as cat if they are cat-lovers, non-smoker if they have recently given up smoking, or sex for reasons that are best left to the reader's imagination.

It should be clear from the above examples that it is often difficult to isolate the effect of one particular tendency on memory. Like ripples on a pond, where two or more aspects complement each other, the overall effect on recall is increased; where they pull in opposite directions, they may cancel each other out. For example, man, woman and sex are schematically linked (at least traditionally) as well as being close together on the page; man and woman are also closely-associated antonyms, familiar and well-entrenched in the mental lexicon, but also relatively unmarked; sex has additional surprise value, as well as being a short, cognate word, and so on.

\section{Memory techniques}

Most of these conclusions may seem unremarkable, but it seems worth repeating them as they are all too often overlooked and their importance underestimated. To recap, it seems that we are more likely to remember: 
GROUPED INFORMATION - i.e. information which is associated in any way

MARKED INFORMATION - i.e. information which is salient in any way take on a very passive role, as if they expect to absorb the vocabulary by osmosis in much the same way that children appear to learn. If they do undertake an active strategy, they tend (in France at least) simply to write translation lists. As such lists seem to remain the students' first choice of vocabulary learning techniques, their use should not be rejected out of hand. Laufer \& Osimo (1991: 218), for example, find that paired word lists are relatively well remembered; O'Malley \& Chamot (1990) find simple repetition to be relatively effective, at least for less advanced learners. Furthermore, students seem to find this practice comfortable through its very familiarity. Certainly, the decontextualised nature of such vocabulary learning has received something of a revival in recent years: Lewis (1993: 17) and Carter (1987: 153) both speak of eliminating the "excess baggage" of context; Cohen\& Aphek (1980: 223) of the "distractions" of context; Lewis (1993: 116) of the "unnecessary confusion" of context (see also Boulton 2006). In any case, it may be accepted that decontextualised learning allows the learner to gain an initial foothold on a lexical item, which can then be expanded by other types of encounter (Nagy 1997).

There are many reasons to believe, however, that lists are not the best way of learning anything, especially not vocabulary; for example, McCarthy (1990: 36) questions whether they enable rapid recall in real communicative situations. In connection with our comments on word groups, translation lists may allow for certain groupings, though it is unclear whether students do actually group items effectively. It appears more likely that they simply list items in chronological order as they encounter them, possibly grouped according to the text or the class subject. They also make minimal use of markedness indeed, the aim is often to make as neat a list as possible. Such an approach may be useful for reference purposes, but the result is precisely the kind of information that the human mind has difficulty in learning.

This criticism can be reformulated in terms of cognitive depth, or levels of processing. The idea was originally developed by Craik \& Lockhart (1972) and Craik \& Tulving (1975), but has been consistently in the literature ever since. The basic idea is that the more deeply one thinks about something, the more deeply the mind processes the information, and thus the higher the probability of long term retention. This is the case with most types of information, but specifically with lexis (Schmitt 1997; Lawson \& Hogben 1996). This led, in the 1980s in particular, to the development of mnemonic techniques to exploit the effect, the most notable of these being "keyword" (Cohen \& Aphek 1980). With this technique, the $\mathrm{L} 2$ target word is unfamiliar, and has to be associated to a well-known item, probably L1; this is the keyword. This primary association is usually phonetic in nature: the learner tries to find a keyword which is phonologically or orthographically similar to the target, though this is often very incongruous. The learner now has a formally-related pair of words: the unfamiliar target to be learned, and the familiar keyword as a hook. The next stage is to create the visual semantic link between them, which should ideally be as striking as possible. In this way, verbal and imagery mnemonics are combined for optimum effect. This can probably best be seen by a very simple example. Imagine a French learner who encounters the word duck in English for the first time: 
L2 target: duck

L1 keyword: duc (cf. English duke)

L1/L2 mental image: a duc with a duck on his head

23 All very interesting, but we must not lose sight of the crucial question: what are the chances the learner will recall the visual image of a duc with a duck on his head the following week or month? Keyword has given rise to a rich body of research, which comes down virtually unanimously in support of it. In one survey, Nation (1993) examined about 60 studies aimed at testing the relative merits of various types of vocabulary learning techniques; he found that mnemonic techniques such as keyword consistently achieve up to $25 \%$ better results than traditional translation lists.

of course, the keyword technique is not without its faults, otherwise all teachers and learners would be using it all the time (see Cohen 1987 for a review of some earlier research). It is often time-consuming to implement, and can hardly be used for all words the learner is likely to need (McCarthy 1990: 118). It can be difficult to use productively (Cohen 1987: 45). It can only provide an initial link, and the item will need a number of further encounters to ensure its effective integration into the mental lexicon (Hulstijn 1997; Schmitt \& McCarthy 1997). In languages such as French and English, the frequent cognates often make it redundant. It may be inappropriate for some words, for example in the case of sub-technical usage (a shaving) or morphologically transparent items ( turnover). Furthermore, learners may reject the technique in toto for a variety of reasons, or simply lack the imagination to put it into practice.

\section{Spontaneous word associates}

What is interesting with keyword is its use of mental imagery; what is often criticised is the highly artificial nature of such images (Ellis 1997; Schouten-van Parreren 1989). To be sure, the links are in no way a reflection of the associations typical of the mental lexicon (see Boulton 1999 for an overview). However, this brings to mind a classroom experience, which may be related anecdotally. When being taught the word to shred for the first time, a group of students spontaneously made an association with Shredder, an evil character from the "Teenage Mutant Ninja Turtles" cartoon series. Unprompted, they played with images of Shredder shredding important documents - an exact, spontaneous and totally untrained imitation of keyword. Incidentally, the target item featured in one of their regular tests some time later, and recall rate was very high:

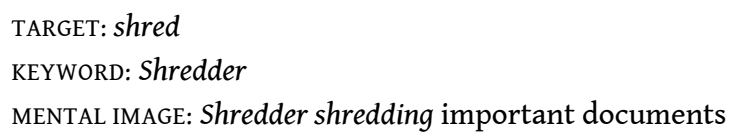

26 If keyword does not reflect the associations of the mental lexicon, it does seem to rely on a natural psychological phenomenon. This gives rise to an obvious question: what kinds of images are students likely to produce spontaneously and without training in such techniques, especially when they are unaware that the association is to be retrieved long term?

27 Some evidence is to be found in another experiment conducted earlier at ESSTIN. As this has been discussed in detail elsewhere (Boulton 1999), we will only give a brief outline here. 89 subjects completed the experiment - all males in their first year at the college, 
with an average age of 18 years 6 months. They all had French L1, and pre-intermediate students (as determined by a placement test) were eliminated from the experiment. The subjects received no explicit training in vocabulary learning techniques other than what they may have previously picked up at school. Twenty pairs of words were presented visually (on computer screen) and orally (through headphones) at the same time. The subjects' task was to describe an association between the two items aloud and in French, their answers being recorded on audiocassette.

One week later the same subjects returned, though again without advance knowledge of either the procedure or the aim of the session. This time they were presented with only one word from each original pair; their task was to retrieve the paired item and also the association they had provided themselves.

The words selected were general English words which students in a pilot run were all familiar with (table 5). Some of the pairs had predicted schematic (e.g. pub/drink) or semantic (e.g. wife/husband) associations, while others were paired randomly (e.g. dog/ motorway).

\section{Table 5. Stimulus list}

\begin{tabular}{|l|l|}
\hline birthday / candle & morning / evening \\
\hline pub / drink & death / god \\
\hline wood / fire & gold / jewellery \\
\hline dog / motorway & rain / goal \\
\hline wife / husband & queen / snow \\
\hline picture / duck & dream / bed \\
\hline newspaper / glasses & red / colour \\
\hline light / armchair & mouse / computer \\
\hline vegetable / bean & work / money \\
\hline shop / sir & car / bicycle \\
\hline
\end{tabular}

The task was in fact rather more complicated than this, as the words were either in English or in French, enabling a comparative analysis of the influence of inter- and intralinguistic L1 and L2 situations. However, to avoid complicating the issue here, we shall only look at data gathered from those students who had stimuli in English. Briefly, it is of note that the students' level (as measured in the placement test) corresponded only very loosely with the number of successful recalls (coef. +0.30 ). Subjects correctly recalled an average of 9.7 answers for the 20 pairs, though scores ranged from 2 to 17 . Students who correctly recalled the association usually also recalled the paired item and vice versa (coef. +0.69). 


\section{Types of association}

31 Some evidence was found for spontaneous keyword imitation. For example, in the case of the snow/rain pair, one student linked the target rain to a keyword renne, giving rise to the following image, correctly recalled in the second session:

Le Père Noël doit se déplacer avec ses rennes.

(Father Christmas needs his reindeer to get around.) ${ }^{1}$

Sometimes students demonstrate remarkable sensitivity to their own thought processes in such areas. The following example speaks for itself, from the think-aloud protocol for vegetable/bean in the second session:

La manière dont je me suis rappelé de ça / c'est assez original / c'est que dans nos groupes / on parle souvent de binôme / et quand on s'appelle entre nous / on appelle notre binôme bin / et donc là ça a fait tilt quand j'ai vu bean. / Bon / ça n'a rien à voir / l'orthographe / ni le sens / mais c'est juste un petit truc comme ça qui m'avait un peu marqué."

(The way I remembered that is quite unusual: we often talk about our binôme (paired student groups), and when we call each other we call our binôme "bin", and that's what I immediately thought of when I saw bean. Of course they're quite different really in terms of both spelling and meaning, but it's just a little thing that struck me .)

The word "marqué" or "struck" is highly apt here. Take the example of queen and snow. Although they were randomly paired, i.e., without a predicted association, they elicited the second highest successful recall rate. This seems to demonstrate the importance of cognitive depth, as subjects had to think hard to create some kind of association which was, furthermore, often visually remarkable. Indeed, those stimuli that elicited some kind of affective response were often well remembered - e.g. "rigolo", "original", "spécial", “ bizarre", or "super", along with associations that had the ability to "plaire" or "choquer":

\footnotetext{
Ça m'avait paru bizarre / l'association des deux mots / alors je m'en suis souvenu.

(That struck me as strange, the association of these two words, and that's why I remembered them.)
}

This can be contrasted with husband/wife, which elicited the highest correct recall rate of all. While this pair is extremely banal and hence unmarked, it is familiar as a pre-existing associated pair of converse antonyms similar to the man/woman pair discussed earlier. Traditional word association experiments (Jenkins 1970) show that man is likely to elicit woman as its prime associate and vice versa, hence the activation of one would automatically produce the other with minimal input from of any specific event memory. In other words, it may be that subjects receiving the stimulus in the second session would automatically produce its paired associate, and only subsequently refer to event memory of the first session to confirm this response. In attempting recall, subjects thinking aloud made often explicit use of virtually all the points mentioned in the first part of this paper, though the overriding kind of association is highly visual, and of one of three types - witness the following sample responses for pub/drink: 
SCRIPT MEMORY: subjects relate a schematic scene typical in the language community:

Un bar est un lieu où / beaucoup de gens / ils viennent pour boire...

(A bar is a place where lots of people go for a drink.)

EVENT MEMORY: subjects recall a particular occasion linking the two items;

Là je pense au bar de l'ESSTIN d'où je viens...

(That makes me think of the ESSTIN bar, as I've just come from there.)

IMAGINED EVENT: subjects create a novel scene drawing on both script and event memory;

On peut imaginer qu'on est assis à un bar / en train de boire / une bonne bière / tranquille / avec des copains tranquilles on boit / on boit un verre dans un / dans un petit bar.

(You can imagine you're sitting at a bar having a drink, a nice pint of beer, relaxing with your friends, and you're having a drink in this little bar.)

\section{Technicality}

Although the list of word pairs presented were not designed to be technical in nature, it might be expected that student engineers (with all the stereotypes that term engenders) would create a number of more or less technical images among their associations. This did indeed happen with some pairs, such as wood/fire:

Le bois est / composé de carbone qui permet une oxydation / donc un dégagement d'énergie calorifique / utilisé pour le chauffage.

(Wood is composed of carbon which allows oxidation and thus the release of calorific energy used for heating.)

C'est grâce à ça certainement que les hommes ont pu développer leur intelligence / en découvrant / une réaction de combustion / dans notre atmosphère. / Sans ça / notre intelligence ne se serait jamais développée.

(This is certainly how mankind's intelligence developed, through discovering the reaction of combustion in our atmosphere; without that, our intelligence never would have developed.)

Such semi-technical descriptions were in fact few and far between, and proved relatively ineffective in the recall session.

One pair of words may be considered as somewhat more technical in nature: mouse/ computer. Of the 22 subjects who had both stimuli in English, 21 created a mental image of a computer and a mouse for this pair; only one student claimed that:

Mickey Mouse n'aime pas les ordinateurs.

(Mickey Mouse doesn't like computers.)

In the recall session, 15 of those 21 subjects managed to recall the paired associate. This is probably due at least in part to the relatively obvious nature of the association between this pair of words; this corresponds to our discussion of recall for husband/wife above.

The case of mouse/computer can be compared with another pair of words, more general in nature: $\mathrm{dog} /$ motorway. This time, the connection between the two is far from obvious in any pre-existing schematic way, but 21 out of the 22 subjects nevertheless created striking visual images, which resulted in 19 instances of successful retrieval in the second session. Typical associations include the following: 
Ça ça me fait penser à une blague si vous connaissez l'histoire de Paf le chien / non bon alors c'est un chien qui va sur l'autoroute et paf le chien / enfin tout le monde a dû la raconter une fois celle-là.

(That makes me think of a joke, do you know the one about Paf ["Splat"] the dog? No? Well, there's this dog that goes on to the motorway and splat the dog. Well, everyone must have told that joke at least once in their lives.)

As might be expected, the more striking the image of death and destruction, the better the chances of recall: ${ }^{2}$

\begin{abstract}
Ah ben oui / celle-là j'oublierai pas / j'avais dit que / les chiens ils avaient pas le droit d'aller sur l'autoroute donc ça allait avec dog / parce que sinon ça faisait écrabouiller schpleurgh / et puis une énorme / marque de bouilli par terre."

(Oh yes right, I won't forget that one. I said that dogs weren't allowed on motorways, so it goes with dog, because otherwise it gets squished schpleurgh, and leaves a huge messy load of pulp on the ground.)
\end{abstract}

\title{
Conclusion
} they seem at times remarkably self-aware, and are apparently capable of transferring a wide range of L1 learning techniques to the L2. A strong claim would emphasise the advantages of explicit training in such skills, and that existing formal avenues require more serious exploration than they have so far received in France. In the light of the perceived rejection of keyword, among other techniques, a weaker claim might be more palatable. It is our contention that, if nothing else, learners would benefit from an increased awareness of how memory functions with regard to various vocabulary learning techniques, sensitising them to what they do "naturally" so that they would be better able to refine their own preferred techniques consciously. 


\section{BIBLIOGRAPHY}

Aitchison, J. 1994. Words in the Mind: An introduction to the mental lexicon. $2^{\text {nd }}$ edition. Oxford: Basil Blackwell.

Boulton, A. 1999. Le lexique mental L2 : Connexions et associations. Lille: Presses Universitaires du Septentrion.

Boulton, A. 2006. “Aspects lexicaux de l'acquisition 'naturelle' et de l'apprentissage 'artificiel' en L2”. Mélanges du CRAPEL 26, 63-90 <http://www.univ-nancy2.fr/CRAPEL/ publications_melanges_26.htm>.

Carter, R.A. 1987. Vocabulary: Applied linguistic perspectives. London: George Allen \& Unwin.

Champagnol, R. 1974. “Association verbale, structuration et rappel libre bilingues”. Psychologie française 19, 83-100.

Cohen, A.D. 1987. "The use of verbal and imagery mnemonics in second language vocabulary learning". Studies in Second Language Acquisition 9-1, 43-62.

Cohen, A.D. \& E. Aphek. 1980. "Retention of second-language vocabulary over time: Investigating the role of mnemonic associations". System, 8-3, 221-235.

Craik, F.I.M. \& R.S. Lockhart. 1972 "Levels of processing: A framework for memory record". Journal of Verbal Learning and Verbal Behaviour 11, 671-684.

Craik, F.I.M. \& E. Tulving. 1975. "Depth of processing and the retention of words in episodic memory". Journal of Experimental Psychology 104, 268-284.

Ellis, N.C. 1997. "Vocabulary acquisition: Word structure, collocation, word-class, and meaning". In Schmitt, N. \& M. McCarthy (eds.), Vocabulary: Description, acquisition and pedagogy. Cambridge: Cambridge University Press, 122-139.

Fromkin, V.A. 1971. “The non-anomalous nature of anomalous utterances”. Language 47, 27-52.

Greene, J. 1987. Memory, thinking and language. London: Methuen.

Hulstijn, J. 1997. "Mnemonic methods in foreign language vocabulary learning: Theoretical considerations and pedagogical implications". In Coady, J. \& T. Huckin (eds.), Second Language Vocabulary Acquisition. Cambridge: Cambridge University Press, 203-224.

Jenkins, J.J. 1970. “The 1952 Minnesota word association norms”. In Postman, L. \& G. Keppel (eds.), Norms of word association. New York: Academic Press, 1-38.

Laufer, B. \& H. Osimo. 1991. "Facilitating long-term retention of vocabulary: The second-hand cloze". System 19/3, 217-224.

Lawson, M.J. \& D. Hogben. 1996. “The vocabulary-learning strategies of foreign-language students”. Language Learning 46/1, 101-135.

Lewis, M. 1993. The lexical Approach. Hove: Language Teaching Publications.

Lindstromberg, S. 1985. "Schemata for ordering the teaching and learning of vocabulary". ELT Journal 39/4, 235-243.

McCarthy, M. J. 1990. Vocabulary. Oxford: Oxford University Press. 
McCarthy, M. J. 1995. “Ten top principles in the design of vocabulary materials". Les après-midi de LAIRDIL Conférence 6, 9-21.

Meara, P. 1982. “Vocabulary acquisition: A neglected aspect of language learning”. In Kinsella, V. (ed.), Language Teaching Surveys. Vol. 1. Cambridge: Cambridge University Press, 100-126.

Nagy, W. 1997. “On the role of context in first- and second-language vocabulary learning”. In Schmitt, N. \& M. McCarthy (eds.), Vocabulary: Description, acquisition and pedagogy. Cambridge: Cambridge University Press, 64-83.

Nation, I.S.P. 1993. "Vocabulary size, growth, and use”. In Schreuder, R. \& B. Weltens (eds.), The Bilingual Lexicon. Amsterdam: Benjamins, 115-134.

O'Malley, J.M. \& A.U. Chamot. 1990. Learning Strategies in Second Language Acquisition. Cambridge: Cambridge University Press.

Schmitt, N. 1997. "Vocabulary learning strategies". In Schmitt, N. \& M. McCarthy (eds.), Vocabulary: Description, acquisition and pedagogy. Cambridge: Cambridge University Press, 199-227.

Schmitt, N. \& M. McCarthy (eds.). 1997. Vocabulary: Description, acquisition and pedagogy, Cambridge: Cambridge University Press.

Schouten-van Parreren, C. 1989. "Vocabulary learning through reading: Which conditions should be met when presenting words in texts?". In Nation, I.S.P. \& R.A. Carter (eds.). AILA review 6: Vocabulary acquisition, Amsterdam: Free University Press, 75-85.

Vigner, G. 1989. "Thèmes, champs lexicaux et activités discursives”. Le Français dans le Monde Numéro spécial: Lexiques, 134-145.

\section{NOTES}

1. It is interesting to note that the rein- in reindeer is etymologically linked to the French renne, both originating in Old Norse.

2. For those readers who are wondering, there is a whole series of jokes along these lines in France, mostly featuring animals as roadkill. The first two of the following are very much in the same childish vein as Paf the Dog; the last two play on the actual paf sound, the last being a play on the word Epiphany: 1) "Floutch" the frog. 2) "Scruik" the snail. 3) "Pafffffffffffffffffffff" the blow-up doll. 4) "Paf" and "Pif": Annie decides to take her dog for a walk in the forest on January 6th. They have to cross the motorway to get there, but a car comes along... et Pafle chien ... et Pif Annie!

\section{ABSTRACTS}

Vocabulary is commonly held to be one of the biggest and most daunting obstacles facing second language (L2) learners. This observation is no doubt due at least in part to the prevalence of inadequate techniques. Many applied linguists have therefore directed their efforts towards exploiting the widely-confirmed psychological phenomenon that durability of memory traces is intimately connected with the affective strength of mental images and associations. In this 
paper, two experiments are described, analysing types of images and associations spontaneously produced by English L2 learners without specific training. In the first experiment, a "random" list of words is presented visually, and recall rates used to demonstrate a variety of psychological phenomena. In the second study, students are tested for production and subsequent recall of lexical associations. Implications are formulated for lexical strategies and for the teaching and learning of $\mathrm{L} 2$ vocabulary.

On prétend souvent que le lexique constitue un des plus grands problèmes pour l'apprenant d'une langue étrangère (L2), certainement dû en partie à l'emploi répandu de techniques inefficaces. De nombreux linguistes en didactique des langues étrangères orientent ainsi leurs recherches vers le lien entre la longévité des traces mémorielles et la force affective des images et associations mentales. Dans cet article, nous analysons différents types d'images et d'associations produites spontanément par des apprenants de l'anglais L2 sans formation dans ces techniques. Lors d'une première expérience, une liste de mots est présentée visuellement et sans ordre apparent; les taux de rappel soulignent un certain nombre de phénomènes psychologiques. Dans une deuxième expérience, nous étudions la production et le rappel ultérieur d'associations lexicales fournies par l'apprenant. Nous en tirons certaines conclusions pour les stratégies lexicales ainsi que pour l'enseignement et l'apprentissage du vocabulaire L2.

\section{INDEX}

Keywords: keyword, language learning (foreign), memory technique, verbal imagery, vocabulary, word association

Mots-clés: apprentissage L2, association lexicale, image verbale, lexique, mnémotechnique, mot clé

\section{AUTHOR}

\section{ALEX BOULTON}

